\title{
Ketotifen and asthma
}

The success of sodium cromoglycate (SCG) as a prophylactic drug for the treatment of allergic diseases has been limited by the need to administer it topically. This has led to a continued search for drugs with similar anti-allergic properties but which can be taken orally and are active systemically. Such drugs would have advantages in the treatment of multi-organ sensitivities and for very young asthmatics unable to use a spinhaler.

Ketotifen has recently been introduced, and promoted, as a clinically effective anti-allergic drug which can be taken by mouth. It is a cycloheptathiophene derivative with strong antihistaminic properties, but more interest has been aroused by its anti-anaphylactic properties. Experimental studies have shown that in vitro the drug can inhibit the antigen-induced release of histamine and slowreacting substance-A from rat mast cells. Like SCG it can also inhibit passive cutaneous anaphylaxis in experimental animals, but current evidence suggests that the mode of action of the two drugs is different. ${ }^{1}$ Studies in man have examined its effect on artificially-induced bronchospasm. Girard and Cuevas ${ }^{2}$ showed that pretreatment with ketotifen had a protective effect against aerosol challenges of offending allergens in adult asthmatics. Further work $^{3}$ confirmed this effect and the degree of protection was found to equal that afforded by pretreatment with SCG. However a study in children ${ }^{4}$ showed there was no benefit from pretreatment with ketotifen in bronchial challenge tests; in this respect it was different from SCG, which gave good protection in children. Exercise-induced wheezing generally responds to prophylactic SCG, and one small study in adults ${ }^{5}$ suggested that ketotifen had a similar prophylactic property.

The evidence from experimental studies in man and animals prompted clinical trials of ketotifen in the prophylaxis of asthma in adults. Several open studies $^{6}{ }^{7}$ and comparisons with clemastine ${ }^{89}$ claimed that ketotifen was of value, but in many cases the trial design was poor. Other studies ${ }^{8-10}$ have compared ketotifen with SCG and have found no difference in symptoms during each period of treatment, concluding that ketotifen had a beneficial effect. However Mattson et al. ${ }^{11}$ compared ketotifen, SCG, and a placebo and found that neither active drug showed any advantage over placebo in a selected group of patients. This work showed the pitfalls of attempting to evaluate one drug by comparing it with another. A more precise doubleblind evaluation of the drug has recently been reported ${ }^{12}$ and this showed a slight beneficial effect of ketotifen in a selected group of asthmatic adults, but many complained of unacceptable drowsiness.

Asthma in children often has a demonstrable allergic component and would be expected to respond well to an effective oral anti-allergic drug. However the assessment of any new treatment for childhood asthma needs carefully controlled trials in view of the intermittent nature of the symptoms and the tendency for spontaneous improvement. Hence claims supporting ketotifen as an effective treatment, which are based on open trials ${ }^{1314}$ are of little value, and comparison with $\mathrm{SCG}^{15}$ can be misleading. Properly designed double-blind trials of ketotifen against placebo suggest that ketotifen is of minimal value, ${ }^{16}$ or of no value $e^{17-19}$ in the prophylaxis of childhood asthma. Excessive drowsiness has not been reported as a side effect in children, but excess weight gain has been noted, probably owing to ketotifen's appetitestimulating properties.

On current evidence, ketotifen appears similar to previously introduced oral anti-allergic drugs-such as doxantrazole or bufrolin sodium. These drugs were effective in vitro and in experimental studies, but they failed to be effective in clinical practice. Ketotifen has been vigorously promoted and proponents have argued the need for longer periods of assessment (of at least 3 months). ${ }^{20}$ However there is little evidence of a cumulative beneficial effect. Indeed its protective effect against artificiallyinduced bronchospasm reached a plateau after 4 weeks' pretreatment. ${ }^{21}$ It may be that further clinical experience will show a beneficial cumulative effect but at present ketotifen is unlikely to replace established prophylactic drugs, and should not be recommended for children.

\section{References}

1 Martin U, Roemer D. Ketotifen, a new type of antianaphylactic agent. Allergol Immunopathol (Madr) 1977; Supplement 5, 5-10.

2 Girard J P, Cuevas M. Anti-asthmatic properties of a new peroral drug (HC 20-511). Acta Allergol (Kbh) 1977; 32: 27-34.

3 Pauwels R, Lamont H, van der Straeten M. Comparison between ketotifen and DSCG in bronchial challenge. Clin Allergy 1978; 8: 289-93.

4 Wells A, Taylor B. A placebo-controlled trial of ketotifen (HC 20-511, Sandoz) in allergen induced 
asthma and comparison with disodium cromoglycate. Clin Allergy 1979; 9: 237-40.

5 Wüthrich B, Radielovic P, Debelic M. The protective effect of ketotifen (HC 20-511) on exercise and aspirininduced asthma. Allergol Immunopathol (Madr) 1977; Supplement 5, 21-6.

6 Labus J, Hlinka V. The clinical effect of ketotifen in bronchial asthma. J Int Med Res 1979; 7: 305-13.

7 Mrackova E, Sach J, Zavázal V, Minarova E, Rickova V. The prophylaxis of asthma using ketotifen. Allergol Immunopathol (Madr) 1977; Supplement 5, 47-50.

8 Craps L, Greenwood C, Radielovic P. Clinical investigation of agents with prophylactic anti-allergic effects in bronchial asthma. Clin Allergy 1978; 8: 373-82.

9 Muhar F, Csajkas G. Oral prophylaxis of bronchial asthma-new approach. Allergol Immunopathol (Madr) 1977; 5: 460-4.

10 Stangl B, Furlan J, Ustar M, Janezic A. The protective effect of ketotifen in bronchial asthma. Respiration 1980; Supplement 1, 12-5.

11 Mattson K, Poppius H, Ahonen A, et al. Comparison of ketotifen, disodium cromoglycate, and placebo in the treatment of adult patients with extrinsic asthma. Respiration 1980; Supplement 1, 20-3.

12 Dyson A J, Mackay A D. Ketotifen in adult asthma. Br Med J 1980; 280: 360-1.

13 Gobel P. Efficacy and tolerability of oral ketotifen in the long term prophylatic treatment of bronchial asthma in children. Pharmatherapeutica $1979 ; 2$ : 153-8.
14 Weheba A S. Prophylactic treatment of bronchial asthma in children with a new orally active agent, ketotifen. Pharmatherapeutica 1979; 2: 147-52.

15 Graff-Lonnevig V, Kusoffsky E. Comparison of the clinical effect of ketotifen and DSCG in pollen-induced childhood asthma. Allergy $1980 ; 35$ : 341-8.

16 Spicak V. Oral prophylaxis of bronchial asthma in children. Respiration 1980; Supplement 1, 18-9.

17 Taylor B, Ford R. Ketotifen in childhood asthma: a double blind placebo controlled trial. Clin Allergy 1979;9: 241-3.

$18 \emptyset$ øterballe O, Nielsen E A L. The protective effect of a new agent, ketotifen syrup, in the treatment of childhood asthma. Allergy 1979; 34: 125-9.

19 Groggins R C, Hiller E J, Milner A D, Stokes G M. Ketotifen in the prophylaxis of childhood asthma. Arch Dis Child 1981 ; 56: 304-5.

20 Spiro S G. Letter: Ketotifen in adult asthma. Br Med J $1980 ; 280: 862$.

21 Mattson K, Poppius H, Nikander-Hurme R. Preventive effect of ketotifen, a new antiallergic agent, on histamineinduced bronchoconstriction in asthmatics. Clin Allergy 1979; 9: 411-6.

J K SARSFIELD

Harrogate General Hospital, Knaresborough Road, Harrogate HG2 7ND, North Yorkshire 